\title{
A new species of the catfish Neoplecostomus (Loricariidae: Neoplecostominae) from a coastal drainage in southeastern Brazil
}

\author{
Arieli Matheus Cherobim ${ }^{1}$, Henrique Lazzarotto ${ }^{2}$ and Francisco Langeani ${ }^{1}$
}

\begin{abstract}
A new species of loricariid catfish is described from the rio Perequê-Açú and surrounding basins, Parati, Rio de Janeiro State. The new species has the accessory process of ceratobranchial 1 more slender than the main body of the ceratobranchial, and a very large sesamoid ossification, markedly greater in size than the interhyal. Additionally, the new species presents a distinct dorsal color pattern consisting of a conspicuous horseshoe shaped light blotch with a central dark area posterior to the supraoccipital.

Uma espécie nova de loricarídeo é descrita do rio Perequê-Açú e bacias circundantes, Parati, Rio de Janeiro. A espécie nova apresenta o processo acessório do ceratobranquial 1 mais delgado do que o corpo principal do ceratobranquial, e uma ossificação sesamoide muito grande, marcadamente maior em tamanho do que o interhial. Adicionalmente, a espécie nova apresenta um padrão de colorido dorsal distinto que consiste em uma conspícua mancha clara em forma de casco de cavalo com uma área escura no centro posterior ao supraoccipital.
\end{abstract}

Keywords: Cascudos, Neoplecostomus microps, Perequê-Açú, Siluriformes, Taxonomy.

\section{Introduction}

Neoplecostomus Eigenmann \& Eigenmann, 1888 was redescribed by Langeani (1990), who proposed the following diagnostic features for the genus: two or three rows of welldeveloped papillae posterior to the dentary teeth, ventral portion of body partially covered by a shield composed of small plates between the pectoral and pelvic fins, and pectoral-fin locking mechanism absent. A phylogenetic analysis performed by Pereira (2008) using morphological data recovered Neoplecostomus as a monophyletic group supported by three exclusive synapomorphies: the pronunced dorsal curvature of the pectoral-fin's unbranched ray, the small expansion of lateropteryium's distal portion, the conspicuous series of papillae posterior to the dentary teeth on the lower lip. However, molecular studies have recovered the genus as non-monophyletic, with Neoplecostomus ribeirensis Langeani, 1990 more closely related to Isbrueckerichthys Derijst, 1996 than to other nominal congeners (Cramer et al., 2011; Roxo et al., 2012a; Roxo et al., 2012b).
Langeani (1990) recognized two valid species for the genus, Neoplecostomus microps (Steindachner, 1876) and $N$. granosus (Valenciennes, 1840), and described four new species: $N$. paranensis from the upper rio Paraná basin, $N$. espiritosantensis from streams of the eastern slopes of Serra do Mar (Espírito Santo State), N. ribeirensis from the rio Ribeira de Iguape basin (São Paulo State) and $N$. franciscoensis from the rio São Francisco basin (Minas Gerais State). Later, N. variipictus, from the rio Paraíba do Sul basin, was described by Bizerril (1995). Several new species were subsequently described for the upper rio Paraná basin: N. bandeirante Roxo, Oliveira \& Zawadzki, 2012c, N. botucatu Roxo, Oliveira \& Zawadzki, 2012c, N. corumba Zawadzki, Pavanelli \& Langeani, 2008, N. jaguari Andrade \& Langeani, 2014, $N$. langeanii Roxo, Oliveira \& Zawadzki, 2012c, $N$. selenae Zawadzki, Pavanelli \& Langeani, 2008 and $N$. yapo Zawadzki, Pavanelli \& Langeani, 2008. Roxo et al. (2014) described $N$. doceensis, the first species from the rio Doce basin.

${ }^{1}$ UNESP, Universidade Estadual Paulista, Instituto de Biociências, Letras e Ciências Exatas, Departamento de Zoologia e Botânica, Laboratório de Ictiologia, Rua Cristóvão Colombo, 2265, 15054-000 São José do Rio Preto, SP, Brazil. (AMC) amcherobim@gmail.com (corresponding author),(FL) langeani@ibilce.unesp.br

${ }^{2}$ Universidade Federal do Rio de Janeiro, Laboratório de Ecologia de Peixes, CCS, Bloco A, sala A-010 Ilha do Fundão, Cidade Universitária, 21941-590 Rio de Janeiro, RJ, Brazil. kiko_lazzarotto@yahoo.com.br 
Neoplecostomus currently comprises 15 species, with most occurring in streams draining the Brazilian Crystalline Shield. The present work describes a new species endemic to four small coastal drainages in the State of Rio de Janeiro.

\section{Material and Methods}

Measurements were taken point to point with digital calipers to the nearest $0.1 \mathrm{~mm}$, on the left side, following Zawadzki et al. (2008). Specimens smaller than 50.0 $\mathrm{mm}$ of SL, were not included in the morphometric and meristics analysis and are assigned as not measured. Plate counts followed Langeani (1990) and Zawadzki et al. (2008), with additional counts of the lateral plate series, following Schaefer (1997). Plates just below the pteroticsupracleithrum, surrounded by a naked area, were not included in the counts of the lateral series. Plates were counted on the left side in both cleared and stained (c\&s) and alcohol-preserved specimens. The former were prepared according to Taylor and Van Dyke (1985). Measurements are presented as percentages of standard length (SL), head length (HL) or other measurements (e.g. snout length/orbital diameter, interorbital lenght/orbital diameter, interorbital lenght/mandibullary width, predorsal length/first dorsalfin ray length, caudal peduncle length/caudal peduncle depth, pelvic-fin length/caudal peduncle depth, lower caudal-fin spine/caudal peduncle depth). The presentation of measurements includes minimum, maximum, mean and standard deviation. Counts are presented as ranges with modes in parentheses. Vertebral counts included five from the Weberian apparatus and one from the hypural plate. Osteological analysis followed Pereira (2008).

Institutional abbreviations are as follows: DZSJRP (Coleção de Peixes do Departamento de Zoologia e Botânica, Universidade Estadual Paulista “Júlio de Mesquita Filho", São José do Rio Preto-SP), LBP (Laboratório de Biologia e Genética de Peixes, Universidade Estadual Paulista "Júlio de Mesquita Filho", Botucatu-SP), MCP (Museu de Ciências e Tecnologia, Pontifícia Universidade Católica do Rio Grande do Sul, Porto Alegre-RS), MNRJ (Museu Nacional, Universidade Federal do Rio de Janeiro, Rio de Janeiro-RJ) and MZUSP (Museu de Zoologia da Universidade de São Paulo, São Paulo-SP).

Fragments of the mitochondrial cytochrome oxidase $\mathrm{c}$ subunit I (COI) gene were sequenced from $N$. microps from rio Paraíba do Sul basin at Silveiras, São Paulo State (four specimens), Cunha, São Paulo State (one), the rio GuapiAçu basin, Rio de Janeiro State (seven), and from rio Macaé basin, Rio de Janeiro State (five). The same region was sequenced from three specimens of the new species from rio Pereque-Açú, Parati in Rio de Janeiro State. Total DNA was extracted from muscle tissue using the salting out method adapted from Miller et al. (1988). The extracted DNA was precipitated with sodium acetate and ethanol, re-suspended in $50 \mu \mathrm{L}$ of ultrapure water, and stored at $-20^{\circ} \mathrm{C}$.
Partial sequences of COI gene were amplified using primers L5698-ASN (5'- AGG CCT CGA TCC TAC AAA GKT TTA GTT AAC -3'; Inoue et al., 2001) and H7271-COI (5'- GTG GTG GGC TCATACAAT AAA-3'; C. Oliveira, pers. comm.).

The polymerase chain reaction (PCR) profile was as follows: one initial cycle of $4 \mathrm{~min}$ at $94^{\circ} \mathrm{C}$, followed by 35 cycles of $1 \mathrm{~min}$ at $94^{\circ} \mathrm{C}, 1 \mathrm{~min}$ at $46^{\circ} \mathrm{C}, 1 \mathrm{~min}$ at $72^{\circ} \mathrm{C}$, and a final extension at $72^{\circ} \mathrm{C}$ for $5 \mathrm{~min}$. The PCR products were purified and both strands were sent for sequencing by MACROGEN Korea.

Sequences were edited using the Seqman II (DNAStar, Inc., http://www.dnastar.com) and aligned by ClustalW in MEGA 6.06 (Tamura et al., 2013). In genetic analyses, the model $\mathrm{TN} 93+\mathrm{G}$ was applied, as suggested by modeltest performed in MEGA 6.06 (Tamura et al., 2013). Levels of gene divergence among the sequences were obtained in MEGA 6.06 (Tamura et al., 2013) and a maximum-likelihood phylogenetic analysis (Swofford \& Berlocher, 1987) was performed using PhyML v 3.0 (Guindon et al., 2010), with supported assessed by 1000 bootstrap replicates. Sequences of COI obtained from GenBank for Neoplecostomus paranensis (Accession number EU179800.1) and Neoplecostomus ribeirensis (Accession number GQ225410.1), were used to root the tree as outgroups.

The vouchers of the new species used in molecular analyses are deposited at DZSJRP under catalog numbers 13914-1, 13914-2 and 20433-1. Mitochondrial DNA sequences from this work were deposited in GenBank (accession codes KU550707 for N. paraty from rio PerequêAçú basin, KU608294 and KU608295 for N. microps from rio Paraíba do Sul basin, KU608296 for rio Guapi-Açu basin, and KU608297 to KU608298 for those from the rio Macaé basin).

\section{Results}

\section{Neoplecostomus paraty, new species}

urn:1sid:zoobank.org:act:7F969D50-0091-4515-928E155ECF67F5B7

\section{Fig. 1}

Neoplecostomus sp. Pereira et al., 2003: 8 (rio Carrasquinho below the Cachoeira do Tobogã, upper Perequê-Açú basin, collected with Hemipsilichthys nimius).

Neoplecostomus parati Malabarba \& Lundberg, 2007: 264 (MCP 32149 , name listed in comparative material, not satisfying provisions of Article 13 of ICZN; a nomen nudum, not available).

Neoplecostomus P sp. n. Pereira, 2008: 28 (species included in phylogenetic analysis).

Holotype. DZSJRP 20429, $82.2 \mathrm{~mm}$ SL, male, Brazil, Rio de Janeiro State, Parati Municipality, coastal drainage, rio PerequêAçú affluent, stream on the road Parati-Cunha, Serra da Bocaina

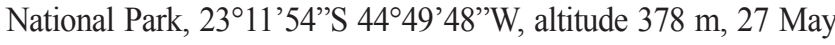
2015, F. Langeani, A. M. Cherobim, H. Lazzarotto \& A. Angulo. 


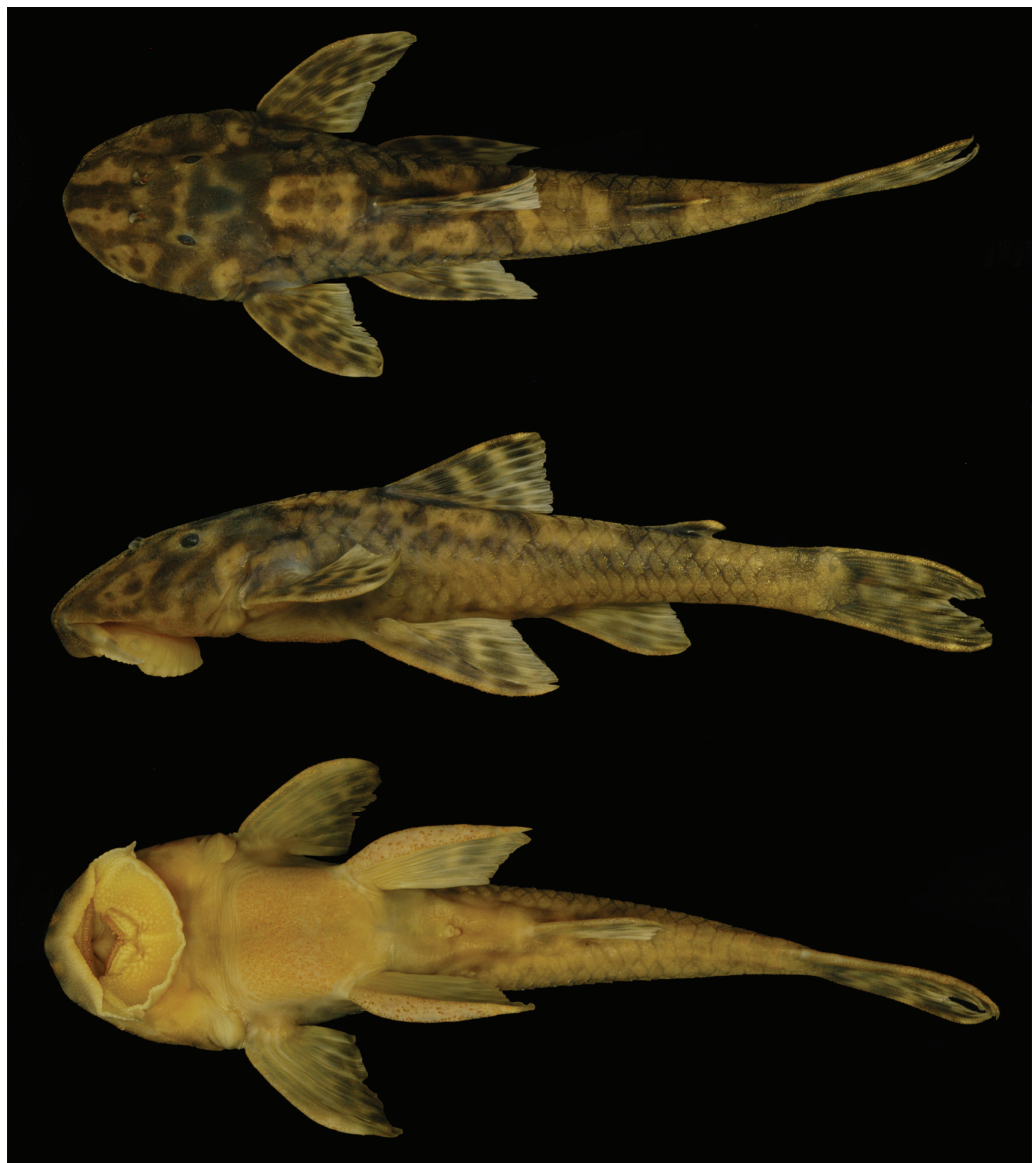

Fig. 1. Holotype of Neoplecostomus paraty, new species, DZSJRP 20429, $82.2 \mathrm{~mm}$ SL, male, stream on the road ParatiCunha, affluent of rio Perequê-Açú, Serra da Bocaina National Park, Parati, Rio de Janeiro State, Brazil.

Paratypes. All from Brazil, Rio de Janeiro State, Parati Municipality, coastal drainage. Rio Perequê-Açú basin: DZSJRP 12481, 10, 44.2-75.3 mm SL (3, 53.5-75.3 $\mathrm{mm} \mathrm{SL}$ ), $1 \mathrm{c \& s}$ (53.5 mm SL, female), tissue samples of 3 specimens, stream on the road Parati-Cunha, near the Serra da Bocaina National Park, 2312'53.5"S
4447'29.0'W, altitude 179 m, 20 May 2010, F. Langeani, M. C. Chiachio \& F. O. Martins. DZSJRP 13914, 8, 32.4$68.3 \mathrm{~mm}$ SL (3, 55.7-68.3 mm SL), 1 c\&s (59.6 mm SL, male), tissue samples of 2 specimens (included in the molecular analysis), stream on the road Parati-Cunha, Penha neighborhood, near Serra da Bocaina National Park, 
$23^{\circ} 12^{\prime} 53.7^{\prime \prime} \mathrm{S} 44^{\circ} 47^{\prime} 28.6^{\prime \prime} \mathrm{W}$, altitude $179 \mathrm{~m}, 2$ Jun 2011 , F. Langeani, M. C. Chiachio \& F. O. Martins. DZSJRP $18726,2,59.3-75.1 \mathrm{~mm}$ SL (all measured), stream on the road Parati-Cunha, in front of the Cantina das Pedras Bar, $23^{\circ} 12^{\prime} 53.5^{\prime \prime S} 44^{\circ} 47^{\prime} 29.0^{\prime \prime} \mathrm{W}$, altitude $179 \mathrm{~m}, 6 \mathrm{Jul}$ 2013, F. Langeani, B. N. Andrade \& A. M. Cherobim. DZSJRP 18733, 1, $35.8 \mathrm{~mm}$ SL (not measured), stream on the road Parati-Cunha, near the village, $23^{\circ} 13^{\prime} 28^{\prime \prime} \mathrm{S}$ 4446'32"W, altitude 38 m, 6 Jul 2013, F. Langeani, B. N. Andrade \& A. M. Cherobim. DZSJRP 20425, 2, 86.8-92.0 mm SL (all measured), rio Perequê-Açú, at the end of the branch road on the road Parati-Cunha, 5 $\mathrm{km}$ from the SP/RJ border, Serra da Bocaina National

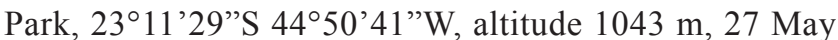
2015, F. Langeani, A. M. Cherobim, H. Lazzarotto \& A. Angulo. DZSJRP 20433, 11, 35.7-66.6 mm SL (5, 51.8$66.6 \mathrm{~mm} \mathrm{SL}$ ), tissue sample of 1 specimen (included in the molecular analysis), rio Carrasquinho, road Parati-

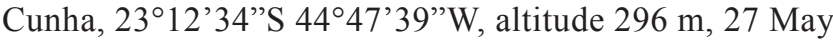
2015, F. Langeani, A. M. Cherobim, H. Lazzarotto \& A. Angulo. MCP 49449, 19, 24.6-61.2 mm SL (7, 51.1-61.2 $\mathrm{mm}$ SL), originally DZSJRP 20433. MNRJ 24914, 3, 46.8-62.8 mm SL, (1, $62.8 \mathrm{~mm} \mathrm{SL})$, rio Carrasquinho, Penha neighborhood, $800 \mathrm{~m}$ upstream of Poço do Tarzan, $23^{\circ} 12^{\prime} 33^{\prime}$ S 444' $38^{\prime \prime}$ W, 20 Feb 2003, H. L. Almeida, U. Fidélis \& G. Southern. MNRJ 41726, 5, 47.3-68.6 mm SL (4, 50.5-68.6 mm), 1 c\&s (50.5 mm SL, female), rio Carrasquinho, road Parati-Cunha, downstream of Penha, $23^{\circ} 12^{\prime} 49^{\prime}$ 'S 4447'29”W, 24 Jun 2013, R. Souza-Lima \& R. R. Rodrigues Junior. MNRJ 44219, 4, 62.0-70.4 mm SL (all measured), Córrego do Sousa, second entrance in the road Caminho do Ouro, near km 9.5, right on the road Parati-Cunha, $23^{\circ} 12^{\prime} 9.8^{\prime \prime S} 44^{\circ} 48^{\prime} 15.0^{\prime \prime} \mathrm{W}$, altitude 417 m, 27 Apr 2014, R. Souza-Lima, R. R. Rodrigues Júnior \& F. V. Guimarães. Rio Graúna basin: DZSJRP 20440, 2, 83.0-90.6 $\mathrm{mm}$ SL (all measured), stream on the right bank of rio Graúna, Graúna's village, $23^{\circ} 08^{\prime} 58^{\prime \prime S}$

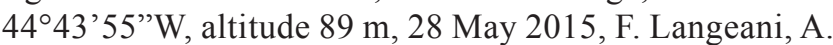
M. Cherobim, H. Lazzarotto \& A. Angulo. Rio Corisco or Mateus Nunes basin: DZSJRP 20442, 22, 35.4-79.3 mm SL $(8,51.0-79.3 \mathrm{~mm} \mathrm{SL})$, tissue sample of 3 specimens, rio Corisco or Mateus Nunes, $23^{\circ} 15^{\prime} 16^{\prime \prime} \mathrm{S} 44^{\circ} 48^{\prime} 18^{\prime \prime} \mathrm{W}$, altitude 386 m, 28 May 2015, F. Langeani, A. M. Cherobim, H. Lazzarotto \& A. Angulo.

Non-types. MNRJ 41727, 12, 30.6-67.5 mm SL (7, 50.1$67.5 \mathrm{~mm} \mathrm{SL}), 1 \mathrm{c} \& \mathrm{~s}(52.0 \mathrm{~mm} \mathrm{SL}$, male), rio Carrasquinho, branch road "Caminho do Ouro em Mãe da Água". The specimens of the lot MNRJ 41727 were measured and counted, but they are not included in the type series due to poor preservation.

Diagnosis. Neoplecostomus paraty differs from most congeners by having the accessory process of ceratobranchial 1 more slender than the main body of the ceratobranchial ( $v s$. accessory process with same width as main body of ceratobranchial in all other Neoplecostomus species, except $N$. corumba, $N$. jaguari and $N$. ribeirensis) (Fig. 2), and a very large sesamoid ossification (rarely small), markedly greater than interhyal (vs. smaller than interhyal in other congeners, except $N$. ribeirensis and $N$. yapo) (Fig. 3). The new species is further diagnosed by having well-developed adipose fin (vs. absent or poorlydeveloped in N. paranensis and N. botucatu); one or two large plates between the humeral process of the cleithrum and the first plate of the lateral series ( $v s$. two or three large plates, arranged in a line, with several small plates above them in $N$. franciscoensis and $N$. ribeirensis); lacking enlarged odontodes and distinct swollen skin along the lateral margins of the snout in mature males (vs. present in $N$. selenae and $N$. yapo); lacking moderate keels along the lateral plate series (vs. present in $N$. bandeirante); lacking enlarged fleshy folds between the dentaries (vs. present in $N$. doceensis); lacking a extra plate with a channel between the canal plate and ventral extremity of the preopercle ( $v s$. present in N. ribeirensis); 29-34 lateral-line plates (vs. 34-43 in N. granosus) and orbital diameter 7.8-10.7\% of HL (vs. 12.2-13.0 in N. corumba). Additionally, $N$. paraty presents a distinct dorsal color pattern: a conspicuous horseshoe shaped light blotch posterior to the supraoccipital, with a central dark area which rarely contacts the edge of the light area (Fig. 1). Furthermore, three other lighter areas with a central dark spot are located at the dorsal-fin base, posterior to dorsal fin, and posterior to the adipose fin.
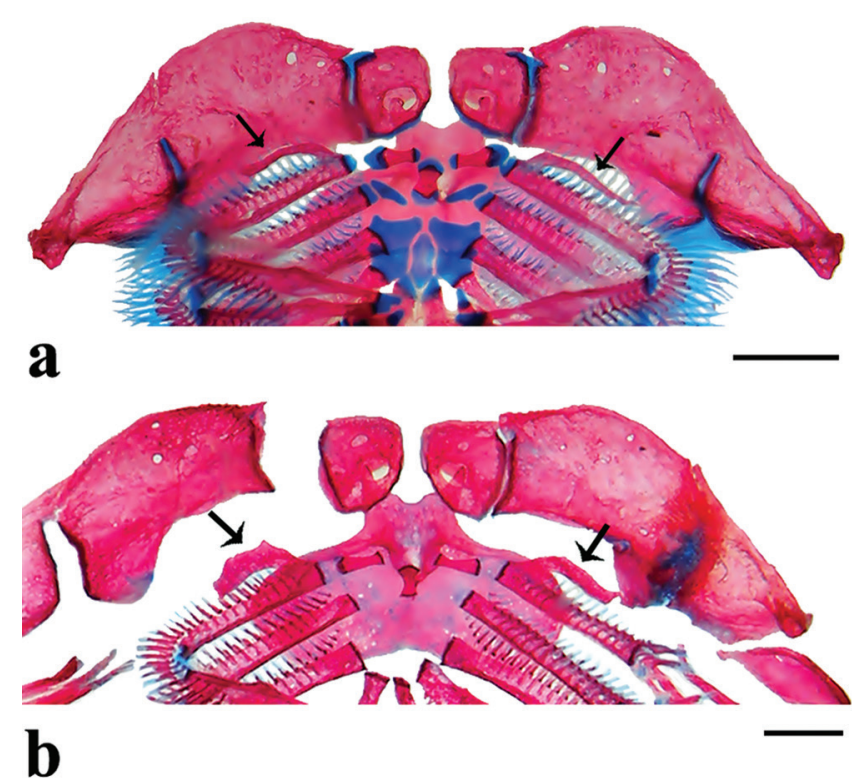

Fig. 2. Branchial skeleton in dorsal view, showing the accessory process of ceratobranchial 1 (black arrow) in (a) Neoplecostomus paraty, DZSJRP 13914, $59.6 \mathrm{~mm}$ SL, male and (b) Neoplecostomus microps, DZSJRP 2144, $62.8 \mathrm{~mm}$ $\mathrm{SL}$, female. Scale bars $=1 \mathrm{~mm}$. 

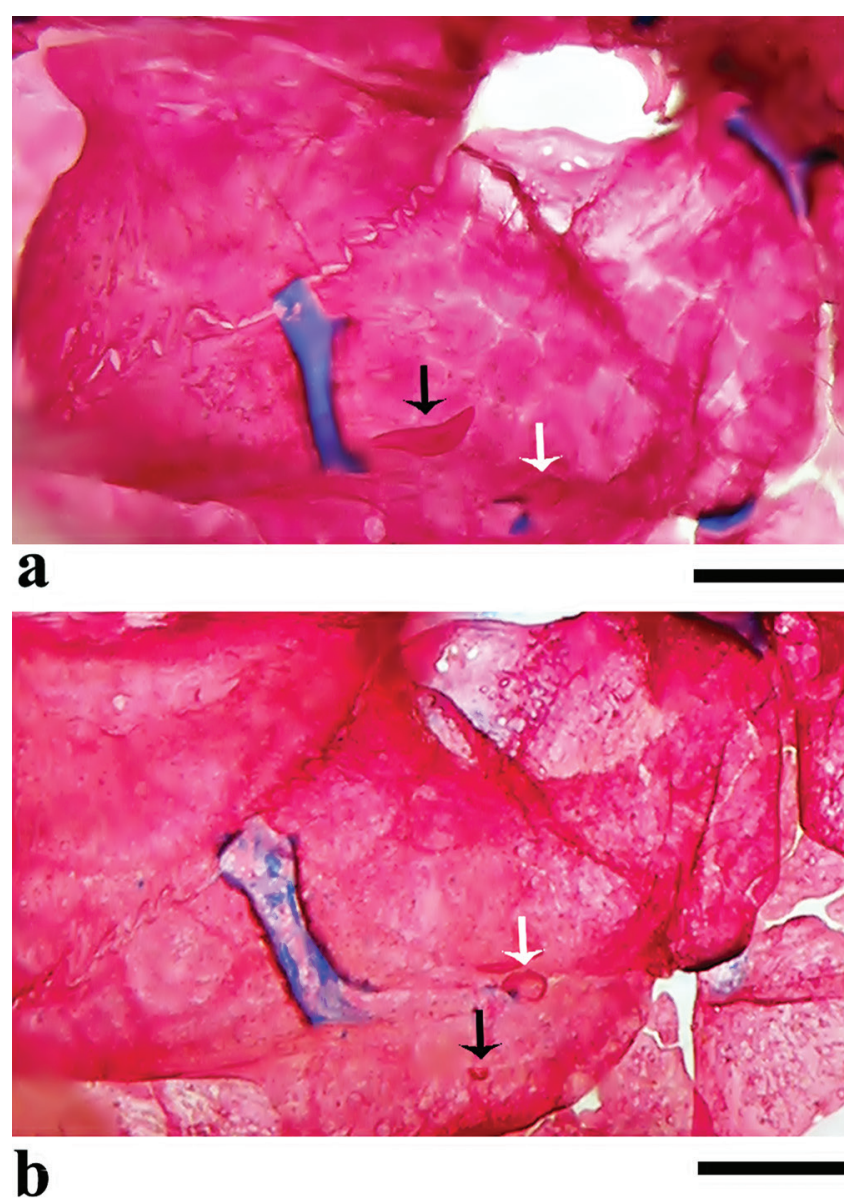

Fig. 3. Right suspensorium in mesial view, showing the size of the sesamoid ossification (black arrow) compared to the size of the interhyal (white arrow) (a) Neoplecostomus paraty, DZSJRP 13914, $59.6 \mathrm{~mm} \mathrm{SL}$, male and (b) Neoplecostomus microps, DZSJRP 2144, $62.8 \mathrm{~mm}$ SL, female. Scale bars $=1 \mathrm{~mm}$.
Description. Measurements and counts given in Table 1. Body elongated and depressed. Greatest body width at cleithrum, narrowing to caudal peduncle. Dorsal body profile gently convex, elevating from snout tip to dorsalfin origin and descending to first caudal-fin ray. Greatest body depth at dorsal-fin origin. Trunk and caudal peduncle dorsally rounded in cross section. Body ventrally flattened to anal-fin origin, flattened to slightly ascending towards caudal fin. Dorsal surface of body completely covered by dermal plates, except for naked area around dorsal-fin base. Snout tip with small naked area. Ventral head surface naked except by canal plate ahead of gill openings. Abdomen with conspicuous and small dermal platelets between insertions of pectoral and pelvic fins, forming thoracic shield (heptagonal- or hexagonal-shaped), surrounded by naked areas. One or two plates, arranged linearly and surrounded by naked areas (rarely with one to three small plates in front of them), between humeral process of cleithrum and first plate of lateral series (only exception in left side of holotype - four plates in line and two small ones in front of them).

Head wide and moderately depressed. Head and snout weakly rounded in dorsal view. Interorbital space slightly convex in frontal view. One median ridge from snout tip to area between nares, another one from posterior naris to anterior margin of orbit. Snout convex in lateral profile. Eye moderately small (7.8-10.7\% of HL), dorsolaterally placed. Iris operculum present. Lips well developed and rounded, covered by papillae. Lower lip not reaching pectoral girdle. Two or three irregular rows of papillae posterior to dentary teeth; papillae large, conspicuous and transversally flattened. Maxillary barbel short, coalesced with lower lip, and generally bifurcated in free portion (some specimens only with fold of skin instead). Teeth long, slender and bicuspid; mesial cusp longer than lateral. Dentary rami forming an angle of approximately $120^{\circ}$.

Table 1. Morphometric and meristic data of Neoplecostomus paraty. $\mathrm{H}=$ holotype, $\mathrm{n}=$ number of specimens and $\mathrm{SD}=$ standard deviation.

\begin{tabular}{|c|c|c|c|c|c|}
\hline & $\mathrm{H}$ & $\mathrm{n}$ & Range & Mean & SD \\
\hline Standard length & 82.2 & 49 & $50.1-92.0$ & 62.6 & 11.0 \\
\hline \multicolumn{6}{|c|}{ Percentage of standard length } \\
\hline Predorsal length & 45.3 & 49 & $41.1-47.3$ & 43.8 & 1.2 \\
\hline Head length & 32.7 & 49 & $28.3-34.1$ & 31.5 & 1.2 \\
\hline Head width & 26.1 & 49 & $22.7-27.8$ & 24.8 & 1.0 \\
\hline Cleithral width & 27.9 & 49 & $23.8-29.1$ & 26.1 & 1.1 \\
\hline Occipital-dorsal distance & 13.8 & 49 & $11.0-14.3$ & 13.0 & 0.9 \\
\hline Thoracic length & 15.1 & 49 & $13.3-17.6$ & 14.9 & 0.9 \\
\hline Interdorsal length & 20.5 & 49 & $17.7-23.5$ & 20.4 & 1.3 \\
\hline Caudal-peduncle length & 28.9 & 49 & $27.7-32.6$ & 30.5 & 1.2 \\
\hline Caudal-peduncle depth & 8.4 & 49 & $7.1-9.1$ & 8.1 & 0.4 \\
\hline Body depth & 17.8 & 49 & $13.1-19.1$ & 16.2 & 1.2 \\
\hline Preanal length & 63.7 & 49 & $61.4-66.9$ & 63.9 & 1.2 \\
\hline \multicolumn{6}{|c|}{ Percentage of head length } \\
\hline Head width & 79.9 & 49 & $74.6-88.4$ & 78.6 & 2.8 \\
\hline Head depth & 51.9 & 49 & $44.2-56.2$ & 49.7 & 2.8 \\
\hline
\end{tabular}


Table 1. (conclusion).

\begin{tabular}{|c|c|c|c|c|c|}
\hline & $\mathrm{H}$ & $\mathrm{n}$ & Range & Mean & SD \\
\hline Snout length & 62.3 & 49 & $58.4-63.8$ & 61.0 & 1.6 \\
\hline Orbital diameter & 8.1 & 49 & $7.8-10.7$ & 9.2 & 0.7 \\
\hline Interorbital width & 29.8 & 49 & $27.6-31.9$ & 29.9 & 1.0 \\
\hline Mandibullary width & 15.3 & 49 & $13.9-21.9$ & 17.1 & 1.7 \\
\hline \multicolumn{6}{|c|}{ Other percentages } \\
\hline Snout length/Orbital diameter & 13.0 & 49 & $12.3-17.5$ & 15.1 & 1.3 \\
\hline Interorbital lenght/Orbital diameter & 27.2 & 49 & $25.8-35.9$ & 30.8 & 2.4 \\
\hline Interorbital lenght/Mandibullary width & 51.2 & 49 & $47.5-78.1$ & 57.5 & 6.3 \\
\hline Predorsal length/First dorsal ray length & 49.5 & 49 & $42.5-56.1$ & 47.6 & 2.8 \\
\hline Caudal peduncle length/ Caudal peduncle depth & 29.1 & 49 & $23.4-32.7$ & 26.7 & 1.8 \\
\hline Pelvic-fin length/ Caudal peduncle depth & 33.1 & 49 & $28.2-38.1$ & 33.4 & 1.9 \\
\hline \multirow[t]{2}{*}{ Lower cd spine/ Caudal peduncle depth } & 31.6 & 46 & $27.4-38.2$ & 31.2 & 2.6 \\
\hline & Counts & & & Mode & \\
\hline Lateral-line plates & 33 & 49 & $29-34$ & 31 & 1.5 \\
\hline Predorsal plates & 4 & 49 & $3-6$ & 4 & 0.6 \\
\hline Plates of dorsal-fin base & 6 & 49 & $4-7$ & 6 & 0.6 \\
\hline Plates between dorsal and caudal fin & 17 & 49 & $16-19$ & 17 & 0.9 \\
\hline Plates between adipose and caudal fin & 8 & 49 & $7-9$ & 8 & 0.7 \\
\hline Plates between anal and caudal fin & 13 & 49 & $11-15$ & 12 & 0.8 \\
\hline Premaxillary teeth & 21 & 49 & $14-24$ & 19 & 2.0 \\
\hline Dentary teeth & 16 & 49 & $13-22$ & 16 & 1.9 \\
\hline Dorsal lateral plate series & 28 & 49 & $26-35$ & 30 & 1.7 \\
\hline Mid-dorsal lateral plate series & 24 & 49 & $24-30$ & 25 & 1.7 \\
\hline Mid-ventral lateral plate series & 24 & 49 & $23-29$ & 24 & 1.7 \\
\hline Ventral lateral plate series & 25 & 48 & $21-31$ & 24 & 1.8 \\
\hline
\end{tabular}

Dorsal-fin ii, 7; origin posterior to vertical passing through pelvic-fin origin. Nuchal plate not covered by skin. Dorsalfin spinelet generally present, half-moon shaped and wider than dorsal-fin first ray base, absent in some specimens; dorsal-fin locking mechanism absent. Dorsal-fin posterior margin slightly falcate, reaching or surpassing vertical through end of pelvic-fin rays when adpressed. Adipose fin present and well developed, preceded by none, one or two azygous plates. Pectoral-fin i,6; with depressed and inward curved unbranched ray, shorter than longest branched ray. Pectoral-fin posterior margin slightly falcate, reaching or nearly reaching half pelvic-fin length when adpressed. Pelvic-fin i,5; posterior margin nearly straight, reaching or nearly reaching anal-fin insertion when adpressed. Pelvicfin unbranched ray ventrally flattened, with dermal flap on dorsal surface in males. Pectoral and pelvic-fin unbranched rays with odontodes on lateral and ventral portions. Analfin i,5; posterior margin nearly straight. Anal-fin unbranched ray only with ventral odontodes. Caudal-fin i, 7,7,i; bifurcate; lower lobe longer than upper. Vertebrae 31-32 (32).

Coloration. Dorsal surface ground color yellowish with light or dark brown blotches. Head with straight yellowish line from snout tip to anterior nares. Another large, less conspicuous and more laterally placed line running from snout border to slightly posterior of nares transverse line. Three other light areas between and around eyes and posterior to opercle and preopercle. Body with four transverse dark brown stripes at anterior portion of dorsalfin base and a little posterior; at posterior portion of dorsalfin base; from vertical through posterior portion of anal-fin base to adipose-fin spine; and at caudal peduncle.

Posterior to supraoccipital, a conspicuous light and horseshoe shaped spot with dark center (Fig. 4a), slightly faded in some specimens (Fig. 4b). Between dorsal dark stripes, three other lighter areas with dark blotches. Juveniles lacking dark blotches or with blotches only slightly demarcated (Fig. 4a). Ventral surface of head and body yellowish medially; light brown laterally from snout tip to region just anterior of anus; light brown posterior of anus to the caudal peduncle. All fins with irregular dark brown areas; sometimes forming inconspicuous transverse stripes. Adipose fin with dark brown spine and hyaline membrane.

Sexual dimorphism. Males with a dermal flap on the anterior dorsal surface of the pelvic fin and a short urogenital papilla posterior to anus, as common for other Neoplecostomus species.

Geographic distribution. Neoplecostomus paraty is known from four small coastal drainages: rio Mateus Nunes (also named rio Corisco), rio Perequê-Açú, rio Graúna, and rio Taquari, Parati, Rio de Janeiro State, southeastern Brazil (Fig. 5). 


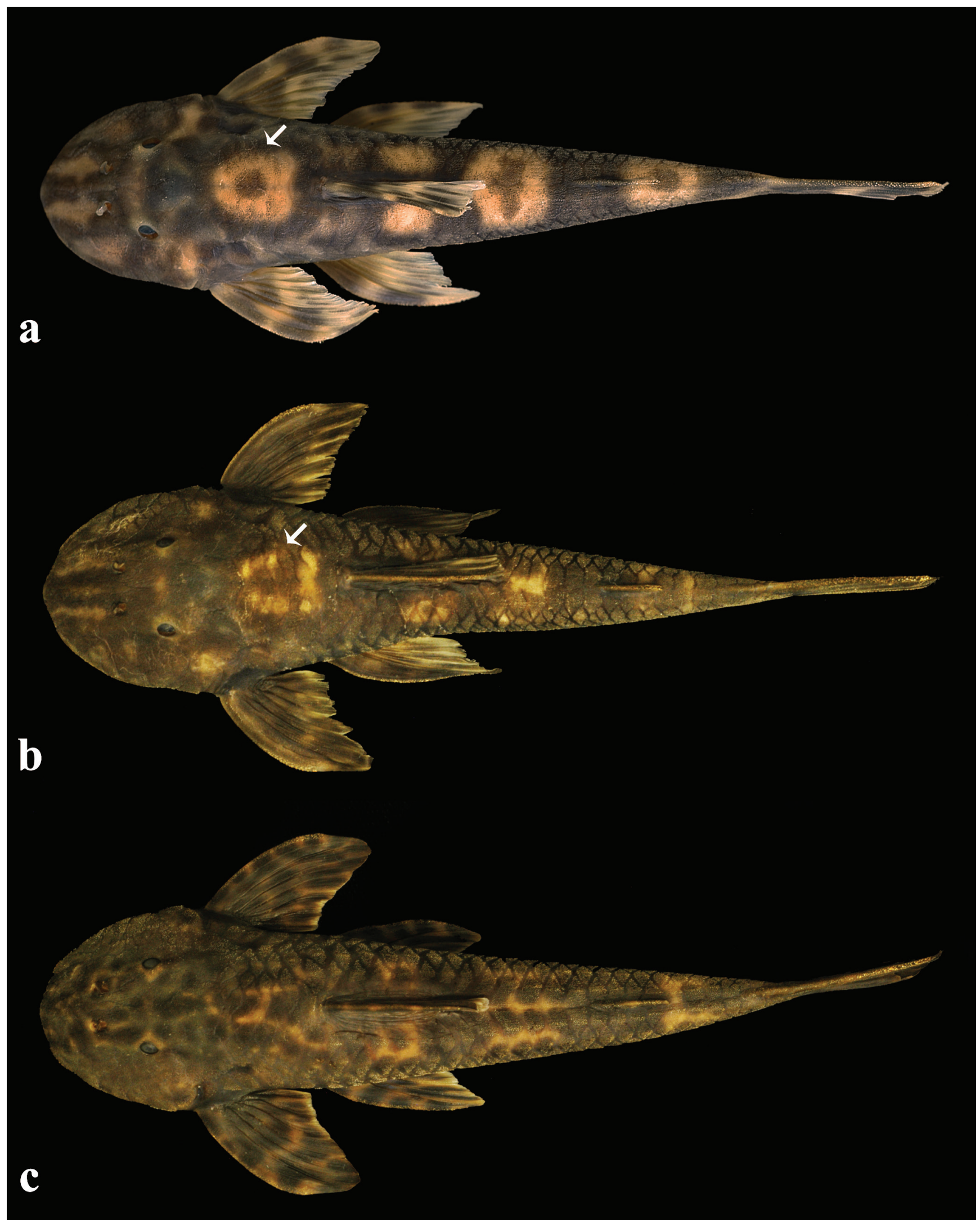

Fig. 4. Color pattern variation in dorsal view of (a) Neoplecostomus paraty, DZSJRP 12481, $58.9 \mathrm{~mm}$ SL, female, (b) Neoplecostomus paraty, DZSJRP 18726, $75.1 \mathrm{~mm} \mathrm{SL}$, male, and (c) Neoplecostomus microps, DZSJRP 13913, $91.6 \mathrm{~mm} \mathrm{SL}$, male. Detail of the light blotch, horseshoe shaped, with a central dark area (white arrow), posterior to supraoccipital. 


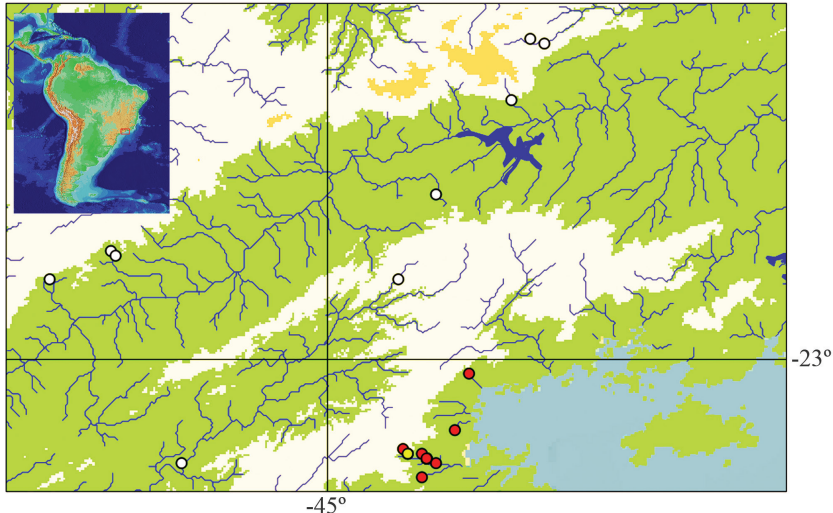

Fig. 5. Southeastern Brazil showing geographic distribution of Neoplecostomus paraty (red circle) and Neoplecostomus microps (white circle). Type locality indicated by yellow circle. Symbols can represent more than one locality.

Ecological notes. Neoplecostomus paraty was found in streams draining the Serra da Bocaina mountain range in the Parati Municipality, with clear and cold water, direct sunlight, fast flow, large rocks at the bottom, depths between 10 to $50 \mathrm{~cm}$ and moderate riparian vegetation (Fig. 6). Some sites in the Parati Municipality are probably among the lowest altitudes (e.g. $38 \mathrm{~m})$ at which Neoplecostomus species have been collected, since the genus commonly occurs at altitudes higher than $700 \mathrm{~m}$. Other loricariids collected together with $N$. paraty are: Kronichthys heylandi (Boulenger 1900), Pareiorhina sp., Hemipsilichthys nimius Pereira, Reis, Souza \& Lazzarotto 2003 and Schizolecis guntheri (Miranda Ribeiro 1918).

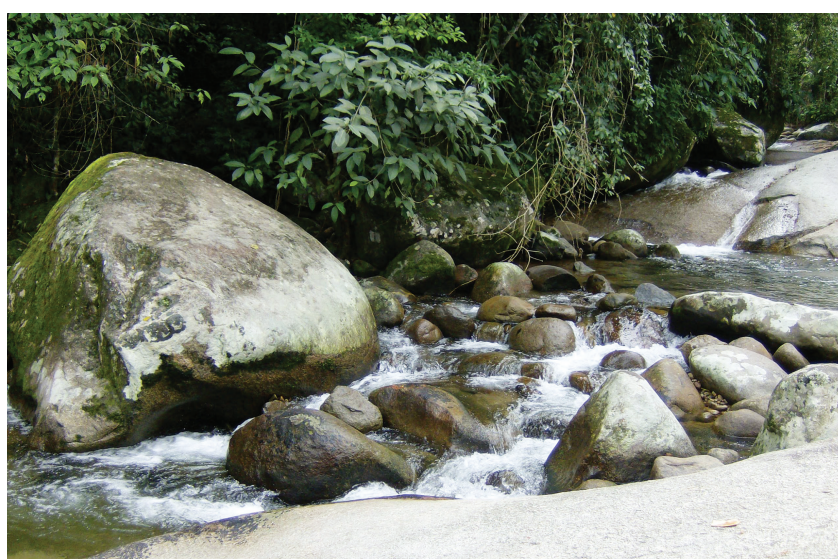

Fig. 6. Stream on the road Parati-Cunha, Penha neighborhood, near Serra da Bocaina National Park, rio Perequê-Açú affluent, coastal drainage, Parati Municipality, Rio de Janeiro State, Brazil, near the type locality of Neoplecostomus paraty.

Etymology. The specific epithet refers to "Paraty", the original spelling of the municipality of Parati, Rio de Janeiro. Paraty (or Paratii) derived from the Tupi "parati" (the mullet Mugil curema Valenciennes, 1836) and "i" (river). A noun in apposition.
Conservation status. Neoplecostomus paraty occurs in four small and independent coastal drainages which run through unprotected land and also some conservation areas, such as Serra da Bocaina National Park and Serra do Mar State Park. The extent to which these conservation areas protect this species is unknown. Outside these parks (and to some extent also within these parks) streams and rivers are threatened by a range of anthropogenic threats associated with urbanization and the growth of the tourist industry, including Parati-Cunha road construction (Avena, 2003). Although $N$. paraty does not meet the criteria for any category of threat (IUCN, 2016), its highly endemic status demands special attention regarding conservation actions, and highlights the importance of the maintenance and even expansion of the protected areas in the region.

Molecular analyses. Partial sequences of the COI gene were taken from 21 specimens, resulting in a matrix with 663 base pairs (bp) from which 559 sites were invariant, 97 were variable, and 35 were parsimony informative. The nucleotide frequencies were, on average, $23.3 \%$ adenine, $25.7 \%$ thymine, $30.7 \%$ cytosine and $20.3 \%$ guanine. A single haplotype was found in both $N$. paraty and the population of $N$. microps from rio Guapi-Açu basin, whereas two haplotypes were found in both populations of $N$. microps from rio Paraíba do Sul and rio Macaé, totaling 6 haplotypes throughout the specimens sequenced. Molecular distances among all assessed populations are given in Table 2 .

Considering the specimens from each basin as separate species or evolutionary units, the intraspecific distance values were zero for $N$. paraty and $N$. microps from GuapiAçu and $0.15 \%$ for both $N$. microps from rio Paraíba do Sul and rio Macaé, due to a single nucleotide different on one specimen each.

A maximum-likelihood analysis showed that haplotypes from each basin are separate lineages well-suported by high bootstrap values (Fig. 7). Lower bootstrap values occur for the clades including more than one lineage within $N$. microps, suggesting that it may be a species complex. The analysis indicates, however, that $N$. paraty is the sister taxon to a clade containing all populations of $N$. microps.

\section{Discussion}

The new species possesses rare osteological features for the genus Neoplecostomus. The slender condition of the accessory process of ceratobranchial 1 is otherwise observed only in $N$. corumba, $N$. jaguari and $N$. ribeirensis, and the very large sesamoid ossification only in $N$. ribeirensis and $N$. yаро. Despite being internal, both characteristics are easily observable and distinguishable, and the latter shows a small intraspecific variability. Furthermore, the dorsal color pattern of $N$. paraty is very conservative and conspicuous, and not seen in any other species within the genus. Other Neoplecostomus species have the general pattern proposed by Langeani (1990), or show a diffuse pattern of smaller 
blotches, both of which are completely different patterns from that displayed by $N$. paraty. Thus, the color pattern is a reliable characteristic which easily distinguishes $N$. paraty from all other species of Neoplecostomus.

Neoplecostomus paraty (as Neoplecostomus $\mathrm{P}$ sp. n.) and N. microps were proposed as sister species by Pereira (2008). Although someuncertainty remains regarding the relationships between these species (and the overall phylogenetic relationships within Neoplecostomus fall beyond the scope of the present paper), the molecular analyses performed herein strongly support that $N$. paraty is a unique evolutionary lineage (Fig. 7). The genetic distance $(>2 \%)$ between $N$. paraty and the remaining populations of $N$. microps (Table 2) provides evidence for a long isolation time and supports $N$. paraty as a new species. Additional phylogenetic analyses are necessary to refine our understanding about the relationships and historical biogeography of $N$. paraty and the $N$. microps species complex.

Table 2. Pairwise mtDNA Tamura Nei + gamma genetic distance values for Cytochrome Oxidase C subunit 1 gene among Neoplecostomus microps from rio Paraíba do Sul, rio Guapi-Açu and rio Macaé, Neoplecostomus paraty, Neoplecostomus paranensis and Neoplecostomus ribeirensis. Alpha-numeric codes below species names are GenBank accession codes. Bold $=$ values greater than $2 \%$. Underline $=$ significant difference between species of Neoplecostomus .

\begin{tabular}{|c|c|c|c|c|c|c|c|}
\hline Taxon & N. microps & aíba do Sul & N. microps Guapi-Açu & N. mic & Macaé & N. paraty & N.paranensis \\
\hline Haplotype & KU608295 & KU608294 & KU608296 & KU608297 & KU608298 & KU550707 & EU179800.1 \\
\hline $\begin{array}{l}\text { N. microps Paraíba do Sul } \\
\text { KU608294 }\end{array}$ & $0.15 \%$ & $\mathrm{X}$ & & & & & \\
\hline $\begin{array}{l}\text { N. microps Guapi-Açu. } \\
\text { KU608296 }\end{array}$ & $1.39 \%$ & $1.54 \%$ & $\mathrm{X}$ & & & & \\
\hline $\begin{array}{l}\text { N. microps Macaé } \\
\text { KU608297 }\end{array}$ & $1.87 \%$ & $\underline{2.03 \%}$ & $\underline{2.36 \%}$ & $\mathrm{X}$ & & & \\
\hline $\begin{array}{l}\text { N. microps Macaé } \\
\text { KU608298 }\end{array}$ & $\underline{2.04 \%}$ & $\underline{2.19 \%}$ & $\underline{2.52 \%}$ & $0.15 \%$ & $\mathrm{X}$ & & \\
\hline N. paraty & $\underline{2.04 \%}$ & $\underline{2.04 \%}$ & $\underline{2.52 \%}$ & $\underline{3.06 \%}$ & $\underline{3.22 \%}$ & $\mathrm{X}$ & \\
\hline N. paranensis & $8.29 \%$ & $8.47 \%$ & $8.88 \%$ & $8.10 \%$ & $8.30 \%$ & $8.08 \%$ & $\mathbf{X}$ \\
\hline N. ribeirensis & $11.38 \%$ & $11.57 \%$ & $12.02 \%$ & $11.21 \%$ & $11.42 \%$ & $12.04 \%$ & $10.88 \%$ \\
\hline
\end{tabular}

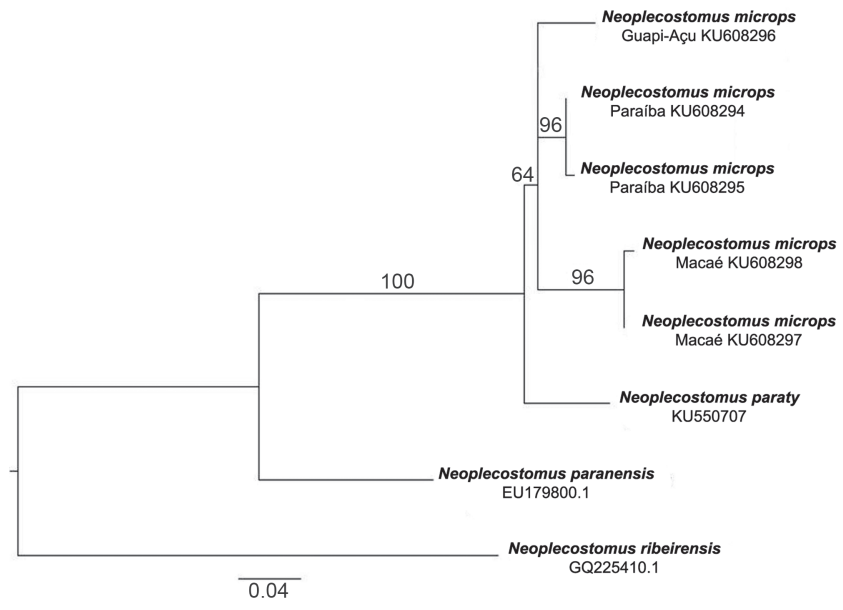

Fig. 7. Maximum-likelihood tree for the mitochondrial DNA gene Cytochrome Oxidase $\mathrm{C}$ subunit 1 for specimens of Neoplecostomus microps from rio Paraíba do Sul, rio GuapiAçu and rio Macaé, and of Neoplecostomus paraty, using TN93+G model $(\mathrm{n}=21)$. Neoplecostomus paranensis and Neoplecostomus ribeirensis were used as outgroups.

Comparative material. All from Brazil. Neoplecostomus bandeirante. All from São Paulo State, Salesópolis Municipality, upper rio Paraná basin, rio Tietê basin, rio Paraitinguinha. DZSJRP 14881, 2, 93.4 and $96.3 \mathrm{~mm}$ SL, paratypes of Neoplecostomus bandeirante Roxo, Oliveira \& Zawadzki, 2012c. LBP 2861, 2 of 24, 75.4 and
$81.7 \mathrm{~mm}$ SL, paratypes of Neoplecostomus bandeirante Roxo, Oliveira \& Zawadzki, 2012c, 1 c\&s (75.4 mm SL, male). Neoplecostomus botucatu. All from São Paulo State, Botucatu Municipality, upper rio Paraná basin, rio Paranapanema basin, rio Pardo affluent. DZSJRP 14879, 6, 55.9-79.9 mm SL, paratypes of Neoplecostomus botucatu Roxo, Oliveira \& Zawadzki, 2012c. LBP 7525, 2 of 21, 76.0 and $76.5 \mathrm{~mm} \mathrm{SL}$, paratypes of Neoplecostomus botucatu Roxo, Oliveira \& Zawadzki, 2012c, 1 c\&s (76.5 mm SL, immature female). Neoplecostomus corumba. All from Goiás State, upper rio Paraná basin, rio Paranaíba basin, rio Corumbá affluent. DZSJRP 6713, 77.8 mm SL, holotype of Neoplecostomus corumba Zawadzki, Pavanelli \& Langeani, 2008, Corumbaíba Municipality. DZSJRP 6193, 5, 43.9-73.7 mm SL, paratypes of Neoplecostomus corumba Zawadzki, Pavanelli \& Langeani, 2008, Corumbaíba Municipality. DZSJRP 7003, 1 c\&s (58.1mm SL, female), Bela Vista de Goiás Municipality. Neoplecostomus espiritosantensis. All from Espírito Santo State. MZUSP 38574-75, 1 of 2, 94.3 mm SL, paratype of Neoplecostomus espiritosantensis Langeani, 1990, Domingos Martins Municipality, rio Jucu. MCP 27340, 3 of 5, 52.6-65.2 mm SL, 1 c\&s $(56.7 \mathrm{~mm} \mathrm{SL}$, male), Muniz Freire Municipality, Terra Corrida stream. Neoplecostomus franciscoensis. All from Minas Gerais State, rio São Francisco basin. MZUSP 37149, 38 of 40, 27.6$73.0 \mathrm{~mm}$ SL, paratypes of Neoplecostomus franciscoensis Langeani, 1990, 1c\&s (unmeasured, dissected), Nova Lima Municipality, rio das Velhas affluent. Neoplecostomus 
jaguari. All from Minas Gerais State, Extrema Municipality, ribeirão do Forja. LIRP 2277, $89.1 \mathrm{~mm} \mathrm{SL}$, holotype of Neoplecostomus jaguari Andrade \& Langeani, 2014. LIRP 2278, 3 c\&s (58.8 mm SL, female, 62.8 and $64.6 \mathrm{~mm} \mathrm{SL}$, males), paratypes of Neoplecostomus jaguari Andrade \& Langeani, 2014. Neoplecostomus langeanii. All from São Paulo State, Muzambinho Municipality, upper rio Paraná basin, rio Grande basin, rio Muzambinho affluent. DZSJRP 4880, 2, 70.1 and $70.3 \mathrm{~mm} \mathrm{SL}$, paratypes of Neoplecostomus langeanii Roxo, Oliveira \& Zawadzki, 2012c. DZSJRP 14882, 6 of 9, 46.0-55.3 mm SL, paratypes of Neoplecostomus langeanii Roxo, Oliveira \& Zawadzki, 2012c. DZSJRP 14049, 13 of 15, 44.5-73.9 mm SL, 1 c\&s (69.1 mm, male). Neoplecostomus microps. All from São Paulo State, rio Paraíba do Sul basin. DZSJRP 2144, 17 of 23, 38.2-83.6 mm SL, $1 \mathrm{c} \& \mathrm{~s}$ (62.8 mm SL, immature female), Cunha Municipality, rio Jacuí-Mirim affluent. DZSJRP 2767, 1 c\&s, (unmeasured, dissected), Cunha Municipality, rio Jacuí-Mirim affluent. DZSJRP 4267, 9, 25.2-53.6 mm SL, São Luís do Paraitinga Municipality, Ribeirão do Chapéu affluent. DZSJRP 4268, 1, 67.1 mm SL, Cunha Municipality, rio Paraitinga affluent. DZSJRP 4269, 5, 18.7-70.5 mm SL, Piquete Municipality, rio Piquete headwaters. DZSJRP 4270, 19, 19.2-78.1 mm SL, São Luís do Paraitinga Municipality, rio Paraibuna affluent. DZSJRP 12727, 2, 59.6-73.7 mm SL, Pindamonhangaba Municipality, rio Piracuama. DZSJRP 13902, 21, 16.3-62.3 mm SL, Silveiras Municipality, Ribeirão Bocaina affluent. DZSJRP 13908, 23, 30.7-79.4 mm SL, Silveiras Municipality, road Silveiras-Cunha, stream in the access on land to the neighborhood Colinas. DZSJRP 13913, 5, 42.7-93.1 mm SL, Cunha Municipality, stream on the royal road Parati-Cunha. DZSJRP 18710, 8, 27.6-83.9 mm SL, Pindamonhangaba Municipality, Ribeirão Grande affluent. DZSJRP 18715, 2, 67.2-67.5 mm SL, Pindamonhangaba Municipality, Ribeirão Grande affluent. DZSJRP 18721, 1, $34.1 \mathrm{~mm}$ SL (unmeasured), Pindamonhangaba Municipality, Ribeirão Grande affluent. DZSJRP 18736, 3, 63.3-80.1 mm SL, 1 c\&s (63.3 mm SL, male), Cunha Municipality, stream on the royal road Parati-Cunha. DZSJRP 20417, 6, 61.9-88.1 mm SL, Bananal Municipality, Ribeirão das Cobras. DZSJRP 20421, 16, 40.6-86.6 mm SL, Bananal Municipality, stream after Bananal Ecological Station. All from Rio de Janeiro State, rio Paraíba do Sul basin. DZSJRP 20342, 4, 17.9-78.3 mm SL, Itatiaia Municipality, Ribeirão Taquari, Itatiaia National Park, lower part. DZSJRP 20346, 5, 22.9-67.3 mm SL, Itatiaia Municipality, Ribeirão Tapera, Itatiaia National Park, lower part. DZSJRP 20353, 1, 66.6 $\mathrm{mm}$ SL, Maringa Municipality, stream on the road PenedoMaromba. DZSJRP 20355, 1, $76.6 \mathrm{~mm}$ SL, Visconde de Mauá Municipality, Marimbondo's river, road PenedoMaromba. DZSJRP 20362, 8, 14.4-69.8 mm SL, Resende Municipality, Alambari river, road Penedo-Maromba. DZSJRP 20367, 7, 27.0-64.4 mm SL, Resende Municipality, Alambari river, road Penedo-Maromba. Neoplecostomus paranensis. MZUSP 38822-824, 3, 33.3-50.4 mm SL, paratypes of Neoplecostomus paranensis Langeani, 1990,
São Paulo State, Cajurú Municipality, upper rio Paraná basin, rio Cubatão. DZSJRP 8590, 10, 17.1-60.5 mm SL, 1 c\&s (60.0 mm SL, male), Minas Gerais State, Fortaleza de Minas Municipality, upper rio Paraná basin, stream between São Sebastião do Paraíso and Passos. Neoplecostomus ribeirensis. All from São Paulo State, rio Ribeira de Iguape basin. MZUSP 35432, 14, 38.2-88.9 mm SL, paratypes of Neoplecostomus ribeirensis Langeani, 1990, 1 c\&s (64.2 mm SL, undetermined sex), Miracatu Municipality, rio Bananal affluent. DZSJRP 13696, 2, 62.5-73.4 mm SL, 1 c\&s (62.5 $\mathrm{mm} \mathrm{SL}$, female), Ibiúna Municipality, rio Itaguapeva. Neoplecostomus selenae. DZSJRP 7449, 4, 56.1-94.7 mm SL, paratypes of Neoplecostomus selenae Zawadzki, Pavanelli \& Langeani, 2008, 1 c\&s (56.3 mm SL, male), São Paulo State, Ribeirão Grande Municipality, upper rio Paraná basin, rio Paranapanema affluent, ribeirão das Batéias. Neoplecostomus variipictus. MNRJ 12806, $89.4 \mathrm{~mm} \mathrm{SL}$, holotype of Neoplecostomus variipictus Bizerril, 1995, Rio de Janeiro State, Nova Friburgo, rio Paraíba do Sul basin, upper rio Bengala. Neoplecostomus yapo. Paraná State, Tibagi Municipality, upper rio Paraná basin, rio Paranapanema basin, rio Tibagi, rio Yapó affluent. DZSJRP 6714, $95.6 \mathrm{~mm}$ SL, holotype of Neoplecostomus yapo Zawadzki, Pavanelli \& Langeani, 2008. DZSJRP 6194, 6, 68.6-103.1 mm SL, paratypes of Neoplecostomus yapo Zawadzki, Pavanelli \& Langeani, 2008, 1 c\&s (69.8 mm SL, male). Neoplecostomus sp. DZSJRP 11464, 3, 44.4-79.1 mm SL, 1c\&s (73.9 mm SL, female), São Roque de Minas Municipality, stream around the Serra da Canastra Nacional Park.

\section{Acknowledgements}

We are grateful to Rosana Souza Lima (UERJ), Paulo A. Buckup (MNRJ), Edson H. L. Pereira (PUC-RS) and Carlos A. S. Lucena (MCP) for the loan of specimens. We are thankful to Arturo Angulo for help during collection of the holotype, to Thiago F. Barros, Rafael Marques, Rômullo Barroso, André Cassino e Fernando Ferraz for help during collection of specimens for the molecular analyses, and to Érica P. Caramaschi and Paulo C. Paiva for use of their respective laboratory facilities at UFRJ. Ecological data was collected on the scope of PROAMA-CpC (Programa de Avaliação de Mananciais, ONG Conhecer para Conservar). We thank Pablo Fernandez, Ubirajara Fidelis, Marcelo Rheingantz, André Castro, Maria Matos, Henrique Jabor and Gregory Southern for the help during field trips. We also thank Fernanda Martins, Breno Neves de Andrade and three anonymous reviewers for valuable contributions to the manuscript and Jon Fong for revising the English version. This study was supported by Fundação de Amparo à Pesquisa do Estado de São Paulo (FAPESP, 2012/04263-3 and 2013/26865-8 to AMC; 2012/23224-9 to FL), Conselho Nacional de Desenvolvimento Científico e Tecnológico (CNPq, 131.179/2014-4 to AMC; 306.566/2014-1 to FL) and Coordenação de Aperfeiçoamento de Pessoal de Nível Superior (CAPES-PROEX to AMC). 


\section{References}

Andrade, B. N. \& F. Langeani. 2014. A new species of Neoplecostomus Eigenmann \& Eigenmann, 1888 (Siluriformes: Loricariidae: Neoplecostominae) from the upper rio Paraná basin. Neotropical Ichthyology, 12: 675-681.

Avena, R. C. S. 2003. Construções rodoviárias, bacias hidrográficas, geração de passivos ambientais e riscos associados: o caso da rodovia RJ-165 - Paraty-Cunha. Unpublished MSc. Dissertation, Universidade do Estado do Rio de Janeiro, Rio de Janeiro, 257p.

Bizerril, C. R. S. F. 1995. Description of a new species of Neoplecostomus (Loricariidae, Neoplecostominae), with a synopsis of the taxonomical composition of the Loricariidae in Eastern Brazil. Arquivos de Biologia e Tecnologia, 38: 693-701.

Cramer, C. A., S. L. Bonatto \& R. E. Reis. 2011. Molecular phylogeny of the Neoplecostominae and Hypoptopomatinae (Siluriformes: Loricariidae) using multiple genes. Molecular Phylogenetics and Evolution, 59: 43-52.

Guindon, S., J. F. Dufayard, V. Lefort, M. Anisimova, W. Hordijk \& O. Gascuel. 2010. New algorithms and methods to estimate Maximum-Likelihood Phylogenies: Assessing the performance of PhyML 3.0. Systematic Biology, 59: 307-321.

Inoue J. G., M. Miya, K. Tsukamoto \& M. Nishida. 2001. A mitogenomic perspective on the basal teleostean phylogeny: resolving higher-level relationships with longer DNA sequences. Molecular Phylogenetics and Evolution, 20: 275-285.

IUCN Standard and Petitions Subcommittee. 2014. Guidelines for Using the IUCN Red List Categories and Criteria. Version 11. Prepared by the Standards and Petitions Subcommittee. Available from http:/www.iucnredlist.org/documents/ RedListGuidelines.pdf (Date of access - 24 March 2015).

Langeani, F. 1990. Revisão do gênero Neoplecostomus Eigenmann \& Eigenmann, 1888, com a descrição de quatro novas espécies do sudeste brasileiro (Ostariophysi, Siluriformes, Loricariidae). Comunicações do Museu de Ciências, PUCRS, série zoologia, 3: 3-31.

Malabarba, M. C. \& J. G. Lundberg. 2007. A fossil loricariid catfish (Siluriformes: Loricarioidea) from the Taubaté Basin, eastern Brazil. Neotropical Ichthyology, 5: 263-270.

Miller, S. A., D. D. Dykes \& H. F. Polesky. 1988. A simple salting procedure for extracting DNA from human nucleated cells. Nucleic Acids Research, 16: 1215.

Pereira, E. H. L. 2008. Relações Filogenéticas de Neoplecostominae Regan, 1904 (Siluriformes: Loricariidae). Unpublished Ph. D. Dissertion, Pontifícia Universidade Católica do Rio Grande do Sul, Porto Alegre, 260p.
Pereira, E. H. L., R. E. Reis, P. F. M. Souza \& H. Lazzarotto. 2003. A new species of the loricariid catfish genus Hemipsilichthys from southern Rio de Janeiro coastal rivers, southeastern Brazil (Teleostei: Siluriformes). Zootaxa, 285: 1-10.

Roxo, F. F., C. Oliveira \& C. H. Zawadzki. 2012c. Three new species of Neoplecostomus (Teleostei: Siluriformes: Loricariidae) from the upper rio Paraná basin of southeastern Brazil. Zootaxa, 3233: 1-21.

Roxo, F. F., G. S. C. Silva, C. H. Zawadzki \& C. Oliveira. 2014. Neoplecostomus doceensis: a new loricariid species (Teleostei, Siluriformes) from the rio Doce basin and comments about its putative origin. ZooKeys, 440: 115-127.

Roxo, F. F., C. H. Zawadzki, M. A. Alexandrou, G. J. C. Silva, M. C. Chiachio, F. Foresti \& C. Oliveira. 2012a. Evolutionary and biogeographic history of the subfamily Neoplecostominae (Siluriformes: Loricariidae). Ecology and Evolution, 2: 24382449.

Roxo, F. F., C. H. Zawadzki, G. J. C. Silva, M. C. Chiachio, F. Foresti \& C. Oliveira. 2012b. Molecular systematics of the armored Neotropical catfish subfamily Neoplecostominae (Siluriformes: Loricariidae). Zootaxa, 3390: 33-42.

Schaefer, S. A. 1997. The Neotropical cascudinhos: systematics and biogeography of the Otocinclus catfishes (Siluriformes: Loricariidae). Proceedings of the Academy of Natural Sciences of Philadelphia, 148: 1-120.

Swofford, D. L. \& S. H. Berlocher. 1987. Inferring evolutionary trees from gene frequency data under the principle of maximum parsimony. Systematic Zoology, 36: 293-325.

Tamura, K., G. Stecher, D. Peterson, A. Filipski \& S. Kumar. 2013. MEGA6: Molecular Evolutionary Genetics Analysis Version 6.0. Molecular Biology and Evolution, 30: 2725-2729.

Taylor, W. R. \& G. C. Van Dike. 1985. Revised procedures for staining and clearing small fishes and other vertebrates for bone and cartilage study. Cybium, 9: 107-119.

Zawadzki, C. H., C. S. Pavanelli \& F. Langeani. 2008. Neoplecostomus (Teleostei: Loricariidae) from the upper rio Paraná basin, Brazil, with description of three new species. Zootaxa, 1757: 31-48.
Submitted June 27, 2016 Accepted September 26, 2016 by Brian Sidlauskas 
